\title{
Editors Committee
}

Prof .Dr /Magda M.Ali Youssef Pediatric Nursing-Alexandria University Prof .Dr / Sanaa Mohamed Alaa EIdeen Medical surgical Nursing -Alexamndria University Prof .Dr / Warda M. Youssef Critical Nursing-Cairo University Prof .Dr / Zienab M. Abd El- Lateef Medical Surgical Nursing-Assiut University Prof .Dr/Magda M.Abd Elazize Medical Surgical Nursing-Ain Shams University Prof .Dr / Nadia M. Fahmey Obst .Nursing Ain Shams University Prof .Dr / Aziza M Atia Obst. Nursing -Ain Shams University Prof .Dr / Sanaa Ali Nour El Dien Obst Nursing-Zagazig University Prof .Dr / Samia Abd El Daym Psychiatric Nursing-Alexandria University Prof .Dr / Sanaa M.Abd Elazize Psychiatric Nursing-Alexandria University Prof .Dr / Zienb Abd El Hamied Loutfy Psychiatric Nursing -Ain Shams University Prof .Dr / Wafaa El Said Ouda Pediatric Nursing - Ain Shams University Prof .Dr /Sohaier Bader El Dien Community Nursing -Cairo University Prof .Dr / Nawal Soliman Community Nursing -Ain Shams University Prof .Dr / Nawal Fouad Community Nursing-Cairo University Prof .Dr / Hoda Diab Fahmy Community Nursing -Assiut University Prof .Dr / Hwida Saddek Community Nursing -Benha University Prof .Dr /Samia M. Abdalla Adm Nursing Administration- Ain Shams University Prof .Dr / Namat M El Sayed Nursing Administration-Damnhour University Prof .Dr / Nihad Ezz El Din Fikry Nursing Administration - Cairo University Prof .Dr / Harisa El Shimmy Nursing Administration - Ain Shams University Prof .Dr / Soad A Ghallab Nursing Administration -Assiut University Prof .Dr / Mervert Aly Kamees Obst. Nursing -Assiut University Prof .Dr / Nagwa Reda Critical Nursing-Alexandria University Prof .Dr / Nefissa Mohamed Psychiatric Nursing - Cairo University Prof .Dr / Amro Ahmed Youssef Cardiology depart -Assiut University Prof .Dr / Mohamed abd el latief Anesthesia depart-Assiut University Prof .Dr /Esam El Sharkawy Abdalla Anesthesia depart -Assiut University Prof .Dr / Hamdy Mahfouz Tropical \&Gastro depart - Al Azhar University Prof .Dr /Ahmed Mohamed El Taher Urology surgery depart -Assiut University Prof .Dr / Samir Shehata Mohamed Eid Oncology depart -Assiut University Prof .Dr / Hassn Abd El Lateff Urology surgery depart -Assiut University Prof .Dr / Fisal Fahmy Adm Orthopedic surgery Medicine -Assiut University Prof .Dr / Safwat Abd El Radi

Obst \& Gynecology depart - Assiut University
Prof.Dr / Samah Mohamed Abdalla Nursing Administration -Assiut University Prof.Dr / Ikram Ibraheem Mohamed Psychiatric Nursing - Assiut University Prof .Dr/Shalabia Elsayed AboZead Medical Surgical Nursing-Assiut University Prof .Dr /Magda Ahmed Mohamed Medical Surgical Nursing-Assiut University Prof .Dr /Nadia Mohamed Tahaa Medical Surgical Nursing-El Zagzig University Prof .Dr /Wfaa Ismael Sheriff Medical Surgical Nursing-El Mansoura University Prof .Dr /Ameraa Ahmed Hasaneen Medical Surgical Nursing-El Mansoura University Prof .Dr / Amel Sobhy Mahmoued Psychiatric Nursing- Port Saied University Prof .Dr / Saidaa Ahmed Abed Latif Psychiatric Nursing - Cairo University Prof .Dr /Kamelia Foad Abd Alla Medical surgical Nursing - Ain Shams University Prof .Dr / Amal m. El dakakny Obst Nursing-Zagazig University Prof .Dr / Rahma Soliman Yousef Obst Nursing-Zagazig University Prof .Dr /Sabah Metoly Mohamed Obst.Nursing Ain Shams University Prof .Dr / shadia abed el kader Obst.Nursing cairo University Prof.dr/ Soumaya A. Badr El Din Gerontological Nursing, Assiut University, Egypt. Prof.dr/ Eman Shokree

Gerontological Nursing, Assiut University, Egypt. Prof.Dr / Fatma Roshdy .M

Nursing Administration -Assiut University Prof .Dr / Safaa Kotb

Community Nursing -Assiut University Prof .Dr / Manal Farouk Obst. Nursing-Assiut University Prof.Dr / Saher Mohamed Morsy

Nursing Administration -Assiut University

INTERNATIONAL EDITORS:

Prof.Dr /Katia Grillo Padilha

(Workload and Patient Safety)Medical surgical nursing - school of nursing

University Of São Paulo - Brazil

Prof.Dr /Ahmed O Kasseb, MD

Associate Professor, Department of Gastrointestinal Medical Oncology, The University of Texas MD Anderson Cancer Center, Houston, Texas.

Prof.Dr / Venessa De Brito Poveda

(Preoperative Nursing)Medical surgical nursing - school of nursing University Of São Paulo - Brazil

Prof.Dr /Lilia De Souza Nogueira

(Intensive Care and Cardiology)Medical surgical nursing - School of Nursing ,University Of São Paulo - Brazil

Prof.Dr /Deborah mc carter - Spaulding $P H D, W H N P-B C, R N, I B C L C$ Associate Professor, St. Anselm College 


\section{Editor in chief :}

Prof / Zeinab Abd El- Lateef Mohamed

Dean of Faculty of Nursing - Assiut University

Associate editor:

Prof / Mimi Mohamed Mekkawy

\section{Editorial board:}

Prof / Samah Mohamed Abdalla

Prof / Hoda Diab Fahmy

Prof / Ikram Ibraheem Mohamed

Prof / Mervat Aly Kamees

Administration secretary:

Ahmed Fathy Ali Frag

Nagah Sayed Abo El Hassan

Mahmoud Ahmed Musa 


\title{
Knowledge and Attitude regarding Global Warming Phenomenon among Assiut University Students
}

\author{
Asmaa A. Ibrahim ${ }^{1}$, Hoda D. Fahmy ${ }^{2} \&$ Safaa R. Mahmoud ${ }^{3}$. \\ 1. Clinical Demonstrator in Community Health Nursing- Faculty of Nursing- Assuit University, Egypt. \\ 2. Professor of Community Health Nursing- Faculty of Nursing- Assuit University, Egypt. \\ 3. Assistant Professor of Community Health Nursing-Faculty of Nursing- Assuit University. Egypt.
}

\begin{abstract}
Background: Global warming is one of the most serious environmental problems of $21^{\text {st }}$ century. The phenomena not only affect human health but also plants, animals, as well as economy and unfortunately some adverse consequences of it, are becoming visible these days. Aim: To assess knowledge and attitude regarding global warming among Assiut University Students. Subjects and methods: A descriptive cross-sectional research design used. This study was carried out on four randomly selected faculties two of them practical and the others two were theoretical. A convenient sample of 1300 students included. Three tools were used the socioeconomic scale, a modified Environmental Issue Questionnaire to assess students' knowledge and a modified Likert's scale to assess students' attitude regarding global warming. Results: The study found that nearly two-thirds of the studied students were in age group of 20 years and more. Also, about half of the studied students had poor knowledge toward global warming and the majority of them had a positive attitude toward the same subject. Conclusion: A significant gap in students' knowledge which needs to be addressed for a better solution to contribute the global warming phenomenon. Recommendations: Integrating environmental concepts into the curriculums for all students from elementary school to university level to increase their environmental awareness about global warming phenomenon.
\end{abstract}

\section{Key Words: Global warming, Knowledge, Attitude, University Students.}

\section{Introduction}

People often not clearly understand the links between the environment and human health. The environment plays a vital role in people's physical, mental and social well-being. It can affect human health in many ways. Some of these effects are immediate and observable, such as drinking contaminated water by sewage and flood water after a hurricane which occurs as a result of global warming (DeMarco \& Harkness 2016).

Global warming is the effect of increasing average temperature of the earth and Oceans due to the increased greenhouse gases mainly carbon dioxide, nitrous oxide, methane, chlorofluorocarbons and ozone that produced from human activities, such as burning of fossil fuel (coal, oil, and natural gas) in vehicles, create electricity, deforestation and various agricultural and industrial practices (Rosidin \& Suyatna 2017\& El-Nagar et al., 2017).

The World Bank described Egypt as particularly vulnerable to global warming effects. Egypt is the fifteenth most populated country in the world and particularly liable to adverse environmental consequences of human-induced climate change. Expected consequences consist of a rise in sea level, water deficiency, agriculture, food insufficiency, and pressures on the health of human and national economy (Saber 2009). The range of projected annual changes and seasonal temperature distribution in Egypt expected by the year 2025 to be $(0.5-1.0$ $\left.{ }^{\circ} \mathrm{C}\right), 2050$ as $\left(1.5-2.0^{\circ} \mathrm{C}\right), 2075$ as $\left(2.0-3.0^{\circ} \mathrm{C}\right)$ and by the year 2100 to be $\left(2.5-4.5^{\circ} \mathrm{C}\right)$ (Hegazy 2009). Climate change also, has important consequences for health such as re-emergence of malaria, asthma, malnutrition, heat-related disorders such as heat stress and heat stroke, infectious diseases, including vector-borne diseases and waterborne diseases, such as childhood gastrointestinal diseases and mental health disorders, such as posttraumatic stress disorder and depression, that are associated with natural disasters. (Sah \& Belled 2015) \& (Patz et al., 2014). Very old and very young people are the most vulnerable groups and tend to have reduced heatregulating mechanisms. Heat-related deaths in the elderly (65 and more years) are projected to increase approximately 47 deaths per 100,000 by 2080 compared to the estimated baseline about one death per 100,000 annually between 1961 and 1990. The reduction in emissions may be decrease heat-related deaths in the elderly to fewer than 9 deaths per 100,000 in 2080 . The poor, the socially isolated, and those already suffering from chronic illness also are likely to be extremely affected by an increase in heat wave frequency and severity (WHO, 2015).

Nurses all over the world should understand the effects of global warming and promote policies and actions which will reduce the process of global warming (Frances \& Glaudia 2013). They are in an excellent position to provide guidance in implementing the principles of reducing, reuse, 
recycle, recover and re-educate in the workplace. Also, nurses can educate people about the environmentally- friendly behaviors such as turn off electrical devices not in use, hanging the laundry outside to dry, driving a fuel-efficient car, use energy effective light bulbs, walking to work, planting trees and use of public transportation(El-Nagar et al., 2017) \& (Hunt 2007).

In the workplace, nurses can teach people to reduce, reuse, and recycle materials to decrease the healthcare impact on the environment. Nurses can also, learn how to promote the safest, most advanced methods of waste disposal, never only burning, which is a polluting and harmful method of waste disposal (Afzal, 2007).

The current study involved male and female undergraduate "university students" aged approximately 17 till 26 year, university students represent a major pool of population also, this is the age of Egyptian students' attainment of university grades (Khalaf, 2012). Knowledge is fact or condition of knowing something with familiarity gained through experience or association. Attitudes are acquired characteristics of an individual. Attitude includes three components: (a) A cognitive or knowledge element (b) an affective or feeling element, and (c) a tendency to action. Attitude has been defined as a relatively enduring organization of beliefs around an object, subject, or concept which predisposes one to respond in some preferential manner (Raina , 2013).

\section{Significance of the study}

Egypt faces serious environmental challenges that can no longer be ignored. Steps must be taken to address this situation, without aggressive and comprehensive corrective measures the situation will deteriorate further. Cairo is considered as one of the most polluted cities on the Earth as well as one of the fastest growing (Fouad 2014).

Additionally, during a practical training at Assiut University Hospitals(Outpatients clinics), we have found a huge number of patients complain from symptoms and signs related to global warming and its effects such as heat stroke so; this study is suggested to increase students' knowledge about this phenomenon.

\section{Aim of the study}

To assess knowledge and attitude of University' students regarding global warming phenomenon.

\section{Research question}

- Are the students have a good level of knowledge regarding global warming phenomenon.

- 2-Are the students have a positive attitude regarding global warming.

\section{Subjects and Methods \\ Research design}

A descriptive cross-sectional research design was used in this study.

Setting

This study was conducted at four randomly selected faculties at Assiut University, two practical faculties called Faculty of Agriculture \& Faculty of Science also, two theoretical faculties called Faculty of Commercial \& Faculty of Law during the academic year 2016-2017.

\section{Target population}

The study involved male and female undergraduate "university students" within age group from 17 to 26 years. This is the age of Egyptian students' attainment of university grades (Khalaf, 2012).

\section{Sampling}

A simple random sampling technique was used in this study.

Assiut University includes from (18) faculties divided into (12) practical colleges and (6) theoretical colleges. This study was conducted at (4) faculties which selected randomly. A convenient sample of 1300 students participated in this study. All grades (first, second, third and fourth grade) were included the study, the researcher enters the available lecture and only the student who available and accept to participate in the study included.

\section{Sample size}

The total numbers of students in the selected faculties were 31149 students, by using software EPI /Info, version 3,3 with $99.9 \%$ confidence interval (CI), the final estimated sample size was 1047 students. To compensate the dropouts, $20 \%$ was added to the sample size; the final sample size was 1300 students; due to the number of students at theoretical faculties more than practical, the sample will be divided as (60\%, 784 students) from theoretical colleges and (40\%, 520 students) from the practical faculties It was divided as the following:

\begin{tabular}{|l|c|c|}
\hline \multicolumn{1}{|c|}{ Faculty } & $\begin{array}{c}\text { Number of } \\
\text { students }\end{array}$ & $\begin{array}{c}\text { Sample } \\
\text { size }\end{array}$ \\
\hline Faculty of Commercial & 14195 & 390 \\
\hline Faculty of Law & 13596 & 390 \\
\hline Faculty of Science & 2364 & 260 \\
\hline Faculty of Agriculture & 994 & 260 \\
\hline Total & $\mathbf{3 1 1 4 9}$ & $\mathbf{1 3 0 0}$ \\
\hline
\end{tabular}

Tools of the study:

Three tools were used in the current study

Tool I: Socioeconomic scale: Which developed by (Abd El-Twab, 2012), it included personal characteristics of the students such as; age, sex, residence and academic year ...,etc. 
Tool II: A modified Environmental Issue Questionnaire developed by (Liarakou et al., 2011) was used to assess students' knowledge about global warming.It included (12) questions such as (factors contributing to climate change, energy resources that cause environmental pollution, effects of the global warming on human, ways of reducing global warming phenomenon.etc.

\section{Scoring system}

The total grades of knowledge equal (34); a grade one was given for each correct answer and zero was given for an incorrect answer and I don't know. There are more than one answer to some questions. The grades for each item were summed and then converted into a percent score as

Poor $=$ score $<50 \%$, Fair $=50-70 \%$ and Good $=$ score $>70 \%$. (Abd El-Rhman 2014 \& Khalaf 2012).

Tool III: A modified Likert's scale developed by (Netravathia \& Chauhan 2014) to assess students' attitude regarding global warming. It was included 12 statements. The responses were based on a threepoint Likert scale (agree, uncertain and disagree). Each item scored $(2,1,0)$ respectively, the scoring reversed for negative statements. Total score calculated by summing up and convert into a percent. The respondent's attitude was considered positive if $60 \%$ or higher and negative if less than $60 \%$ (Ibrahim et al., 2009).

\section{Validity of tools}

To evaluate the sheet validity, it was reviewed by 5 experts in nursing sciences, Assiut University. The necessary modifications and clarifications of some questions were done.

\section{Reliability of tools}

A reliability analysis was carried out in order to examine the internal consistency of its questions. The value of Cronbach's alpha was 0.835 for knowledge, and 0.779 for attitude implying that the instrument was consistent and reliable in achieving the study objectives.

\section{Methods}

\section{A. Administrative phase}

Before conducting the study an official approval letter was obtained from the dean of Faculty of Nursing, Assiut University to the vice of University president for students' affairs of Assiut University and the Deans of each selected faculty. The letter included a permission to carry out the study and explained the purpose and the nature of the study.

\section{Pilot Study}

A pilot study was carried out before starting data collection on (20) students were not included in the total sample of the research work. The aims of pilot study to test clarity, feasibility and consistency of the tools.

\section{Data collection Phase Ethical consideration}

The researcher followed all the ethical issues in conducting the research. Consent was secured orally from the participants who were willing to participate in the study. The participants were informed that participation in this study is voluntary; they can withdraw at any time during the study without giving reasons. The researchers have explained the aim of the study to all university students in the study sample. They reassured that any obtained information would be strictly confidential.

\section{Field work}

- Data were collected during the period from the first of October to the middle of December 2016. The average time taken for completing questionnaires was around 20-25 minutes.

\section{Statistical analysis}

- The data obtained were reviewed, prepared for computer entry, coded, analyzed and tabulated. Descriptive statistics (i.e., frequencies, percentage, mean and standard deviation) were done by using Statistical Package for Social Science (SPSS) software (version 20).

- Chi-square test and Pearson's correlation used to see associations among different variables. It is considered significant when P-values were less than $0.05(\mathrm{P}<0.05)$. 
Results

Table (1): distribution of the students regarding to their Socio-demographic characteristics $(n=1300)$.

\begin{tabular}{|l|c|c|}
\hline \multicolumn{1}{|c|}{ Characteristics } & No. $(\mathbf{n}=\mathbf{1 3 0 0})$ & \% \\
\hline Age & 468 & 36.0 \\
\hline$<20$ & 832 & 64.0 \\
\hline$\geq 20$ & \multicolumn{2}{|c|}{$20.08 \pm 1.34(17.0-25.0)$} \\
\hline Mean \pm SD (Range) & 356 & 27.4 \\
\hline Academic year & 282 & 21.7 \\
\hline $1^{\text {st }}$ year & 345 & 26.5 \\
\hline $2^{\text {nd }}$ year & 317 & 24.4 \\
\hline $3^{\text {rd }}$ year & \multicolumn{2}{|c|}{} \\
\hline $4^{\text {th }}$ year & 697 & 53.6 \\
\hline Sex & 603 & 46.4 \\
\hline Male & \multicolumn{2}{|c|}{} \\
\hline Female & 730 & 56.2 \\
\hline Residence & 570 & 43.8 \\
\hline Rural & & \\
\hline Urban & 230 & 17.7 \\
\hline Socioeconomic level & 824 & 18.9 \\
\hline Low & 246 & \\
\hline Middle & \multicolumn{2}{|c|}{} \\
\hline High & \multicolumn{2}{|c|}{} \\
\hline
\end{tabular}

Table (2): distribution of the studied students regarding to their knowledge about the factors contributing to climate changes and energy resources,Assiut University 2016-2017, $(\mathbf{n}=1300)$.

\begin{tabular}{|c|c|c|}
\hline Knowledge & No. $(n=1300)$ & $\%$ \\
\hline \multicolumn{3}{|l|}{ Factors contributing to climate changes ${ }^{(\nexists)}$} \\
\hline 1. Melting Polar Regions & 607 & 46.7 \\
\hline 2. Human activities such as the exhaust fumes of cars & 932 & 71.7 \\
\hline 3. Increase in the worldwide average of sea level & 415 & 31.9 \\
\hline 4. Deforestation and logging & 818 & 62.9 \\
\hline 5. Industrial Pollution & 886 & 68.2 \\
\hline 6. Waste of non-renewable energy resources such as natural gas & 366 & 28.2 \\
\hline 7. The use of coal and industrial fertilizers & 631 & 48.5 \\
\hline 8. Use of solar energy & 186 & 14.3 \\
\hline 9. Burning of agricultural wastes & 848 & 65.2 \\
\hline 10. Burning of waste materials & 862 & 66.3 \\
\hline 11. Don't know & 52 & 4.0 \\
\hline \multicolumn{3}{|l|}{ Energy resources that cause environmental pollution } \\
\hline $\mathrm{Coal}^{(1)}$ & 769 & 59.2 \\
\hline Oil $^{(\wedge)}$ & 403 & 31.0 \\
\hline Natural gas & 39 & 3.0 \\
\hline Solar & 11 & 0.8 \\
\hline Don't know & 78 & 6.0 \\
\hline
\end{tabular}


Table (3): Distribution of the studied sample regarding to knowledge about the effects of global warming on human health, Assiut University 2016-2017, $(\mathrm{n}=1300)$.

\begin{tabular}{|l|l|l|}
\hline \multicolumn{1}{|c|}{ Knowledge } & \multicolumn{1}{c|}{ No. (n= 1300) } & \% \\
\hline \hline Effects of the global warming on humans health ${ }^{(\neq)}$ & & 36.2 \\
\hline Increase the psychological stress & 470 & 14.9 \\
\hline Malnutrition & 194 & 38.0 \\
\hline Increase the transmission of diseases & 494 & 21.0 \\
\hline Contamination of drinking water & 273 & 47.6 \\
\hline Respiratory problems & 619 & 34.5 \\
\hline Skin burns & 449 & 46.1 \\
\hline Increase the incidence of skin cancers & 599 & 14.2 \\
\hline Don't know & 185 & \\
\hline
\end{tabular}

(₹) More than one answer was selected.

Table (4): Distribution of the studied sample regarding to knowledge about ways of reducing global warming phenomenon and Sources of alternative energy, Assiut University 2016-2017, $\mathbf{n = 1 3 0 0 .}$

\begin{tabular}{|c|c|c|}
\hline Knowledge & No. $(n=1300)$ & $\%$ \\
\hline \multicolumn{3}{|l|}{ Ways of reducing global warming phenomenon ${ }^{(\nexists)}$} \\
\hline Decrease electricity consumption & 276 & 21.2 \\
\hline Industrial Security & 672 & 51.7 \\
\hline Traffic security and car maintenance & 585 & 45.0 \\
\hline Use of bikes & 635 & 48.8 \\
\hline Don't know & 181 & 13.9 \\
\hline \multicolumn{3}{|l|}{ Sources of alternative energy ${ }^{(\supsetneqq)}$} \\
\hline Sun energy & 1051 & 80.8 \\
\hline Hydraulic power generated by the natural movement of water in the rivers & 598 & 46.0 \\
\hline Wind Energy & 799 & 61.5 \\
\hline Don't know & 97 & 7.5 \\
\hline
\end{tabular}

(\#) More than one answer was selected.

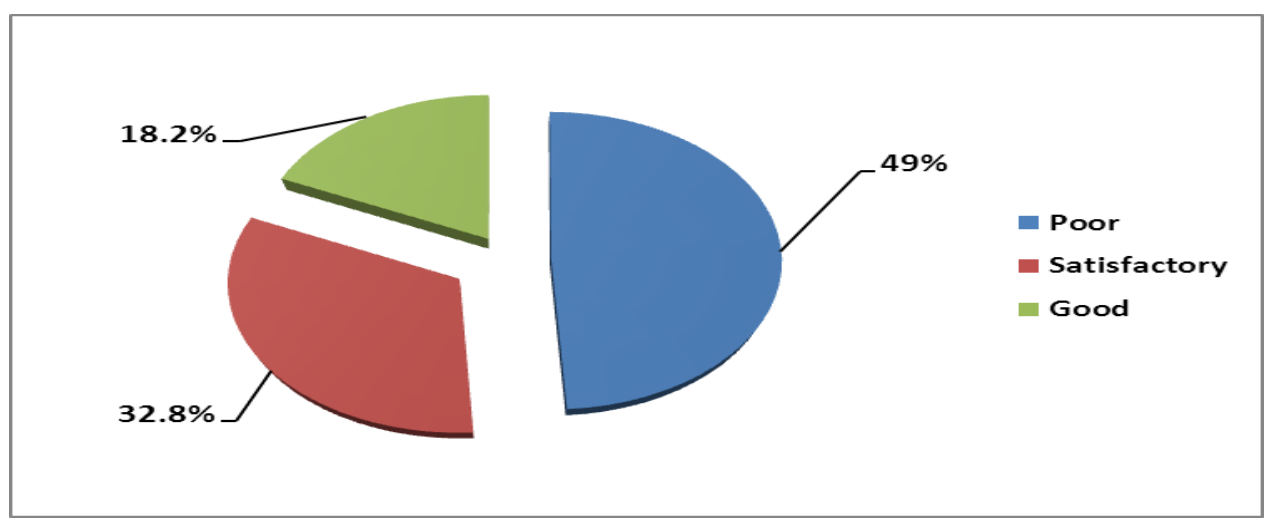

Fig. (1): Distribution of studied students according to their total score of knowledge regarding global warming, Assiut university 2016-2017, $(n=1300)$. 


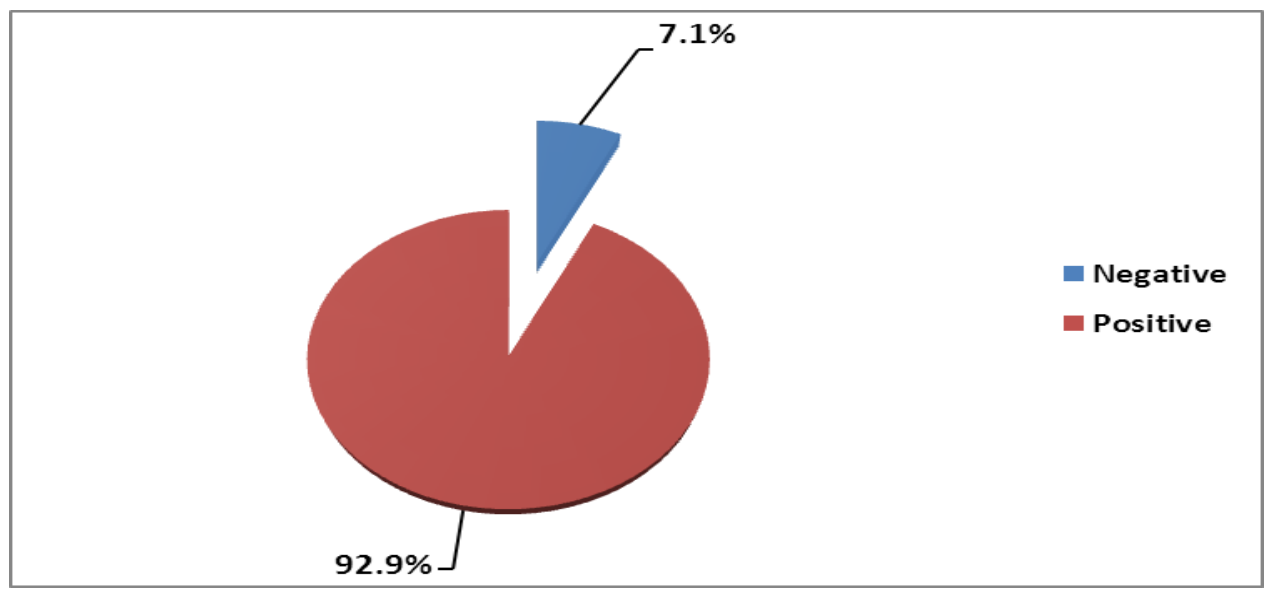

Fig. (2): Distribution of studied students according to their attitude toward global warming, Assiut university 2016-2017, $(n=1300)$.

Table (5): Relationship between total score of students' knowledge and their Institution \& Academic year, Assiut University 2016-2017, $(n=1300)$.

\begin{tabular}{|c|c|c|c|c|c|c|c|c|}
\hline \multirow{3}{*}{ Characteristics } & \multicolumn{6}{|c|}{ Score of Knowledge } & \multirow{3}{*}{$\mathbf{X} 2$} & \multirow{3}{*}{ P-value } \\
\hline & \multicolumn{2}{|c|}{ Poor } & \multicolumn{2}{|c|}{ Satisfactory } & \multicolumn{2}{|c|}{ Good } & & \\
\hline & No. & $\%$ & No. & $\%$ & No. & $\%$ & & \\
\hline Institution & & & & & & & \multirow{5}{*}{54.79} & \multirow{5}{*}{$0.000^{*}$} \\
\hline Faculty of Commerce & 159 & 40.8 & 144 & 36.9 & 87 & 22.3 & & \\
\hline Faculty of Law & 241 & 61.8 & 109 & 27.9 & 40 & 10.3 & & \\
\hline Faculty of Agriculture & 135 & 51.9 & 70 & 26.9 & 55 & 21.2 & & \\
\hline Faculty of Science & 102 & 39.2 & 103 & 39.6 & 55 & 21.2 & & \\
\hline \multicolumn{7}{|l|}{ Academic year } & \multirow{5}{*}{19.71} & \multirow{5}{*}{$0.003 *$} \\
\hline $1^{\text {st }}$ year & 168 & 47.2 & 127 & 35.7 & 61 & 17.1 & & \\
\hline $2^{\text {nd }}$ year & 152 & 53.9 & 87 & 30.9 & 43 & 15.2 & & \\
\hline $3^{\text {rd }}$ year & 187 & 54.2 & 103 & 29.9 & 55 & 15.9 & & \\
\hline $4^{\text {th }}$ year & 130 & 41.0 & 109 & 34.4 & 78 & 24.6 & & \\
\hline
\end{tabular}

* Statistical significance difference.

Table (6): Relationship between students' attitude toward global warming and their Institution \& Academic year, Assiut university 2016-2017, $(n=1300)$.

\begin{tabular}{|c|c|c|c|c|c|c|}
\hline \multirow{3}{*}{ Characteristics } & \multicolumn{4}{|c|}{ Attitude } & \multirow{3}{*}{$\mathbf{X} 2$} & \multirow{3}{*}{ P-value } \\
\hline & \multicolumn{2}{|c|}{ Negative } & \multicolumn{2}{|c|}{ Positive } & & \\
\hline & No. & $\%$ & No. & $\%$ & & \\
\hline Institution & & & & & \multirow{5}{*}{27.13} & \multirow{5}{*}{$0.000 *$} \\
\hline Faculty of Commerce & 18 & 4.6 & 372 & 95.4 & & \\
\hline Faculty of Law & 26 & 6.7 & 364 & 93.3 & & \\
\hline Faculty of Agriculture & 37 & 14.2 & 223 & 85.8 & & \\
\hline Faculty of Science & 11 & 4.2 & 249 & 95.8 & & \\
\hline \multicolumn{5}{|l|}{ Academic year } & \multirow{5}{*}{25.58} & \multirow{5}{*}{$0.000 *$} \\
\hline $1^{\text {st }}$ year & 20 & 5.6 & 336 & 94.4 & & \\
\hline $2^{\text {nd }}$ year & 37 & 13.1 & 245 & 86.9 & & \\
\hline $3^{\text {rd }}$ year & 26 & 7.5 & 319 & 92.5 & & \\
\hline $4^{\text {th }}$ year & 9 & 2.8 & 308 & 97.2 & & \\
\hline
\end{tabular}


Table (7): Distribution of studied Student according to their Attitude toward global warming, Assiut University 2016-2017, $(n=1300)$.

\begin{tabular}{|l|c|c|c|c|c|c|}
\hline \multicolumn{1}{|c|}{ Items } & \multicolumn{2}{|c|}{ Agree } & \multicolumn{2}{c|}{ Uncertain } & \multicolumn{2}{c|}{ Disagree } \\
\cline { 2 - 7 } & No. & $\%$ & No. & \% & No. & $\%$ \\
\hline $\begin{array}{l}\text { 12. I believe that global warming phenomenon is } \\
\text { universal phenomena. }\end{array}$ & 1152 & 88.6 & 127 & 9.8 & 21 & 1.6 \\
\hline $\begin{array}{l}\text { 13. I assume that global warming phenomenon } \\
\text { situation has created shortage of food. }\end{array}$ & 567 & 43.6 & 643 & 49.5 & 90 & 6.9 \\
\hline $\begin{array}{l}\text { 14. I feel that a global warming phenomenon is } \\
\text { only propaganda. }\end{array}$ & 61 & 4.7 & 168 & 12.9 & 1071 & 82.4 \\
\hline $\begin{array}{l}\text { 15. I feel that a global warming phenomenon has } \\
\text { affected human health. }\end{array}$ & 1163 & 89.5 & 116 & 8.9 & 21 & 1.6 \\
\hline $\begin{array}{l}\text { 16. I feel that the study of global warming } \\
\text { phenomenon is necessary; due to its influence } \\
\text { on the environment. }\end{array}$ & 996 & 76.6 & 168 & 12.9 & 136 & 10.5 \\
\hline $\begin{array}{l}\text { 17. I think that occurrence of climate change has } \\
\text { increased soil evaporation rate. }\end{array}$ & 496 & 38.2 & 700 & 53.8 & 104 & 8.0 \\
\hline $\begin{array}{l}\text { 18. I think no need to waste resources on climate } \\
\text { change issue. }\end{array}$ & 231 & 17.8 & 471 & 36.2 & 598 & 46.0 \\
\hline $\begin{array}{l}\text { 19. I think climate change phenomena have } \\
\text { increased natural calamities. }\end{array}$ & 953 & 73.3 & 292 & 22.5 & 55 & 4.2 \\
\hline $\begin{array}{l}\text { 20. I feel that change in rainfall pattern is mainly } \\
\text { due to climate change. }\end{array}$ & 871 & 67.0 & 367 & 28.2 & 62 & 4.8 \\
\hline $\begin{array}{l}\text { 21. I think lack of sensitivity towards climate } \\
\text { change creates vulnerability in agriculture. }\end{array}$ & 987 & 75.9 & 270 & 20.8 & 43 & 3.3 \\
\hline $\begin{array}{l}\text { 22. I feel that because of climate change and } \\
\text { global warming phenomenon there is need to } \\
\text { adopt innovative methods in farming and } \\
\text { industry. }\end{array}$ & 1104 & 84.9 & 157 & 12.1 & 39 & 3.0 \\
\hline $\begin{array}{l}\text { 23. I feel that global warming is the natural } \\
\text { phenomena so man has nothing to do with it. }\end{array}$ & 251 & 19.3 & 234 & 18.0 & 815 & 62.7 \\
\hline
\end{tabular}

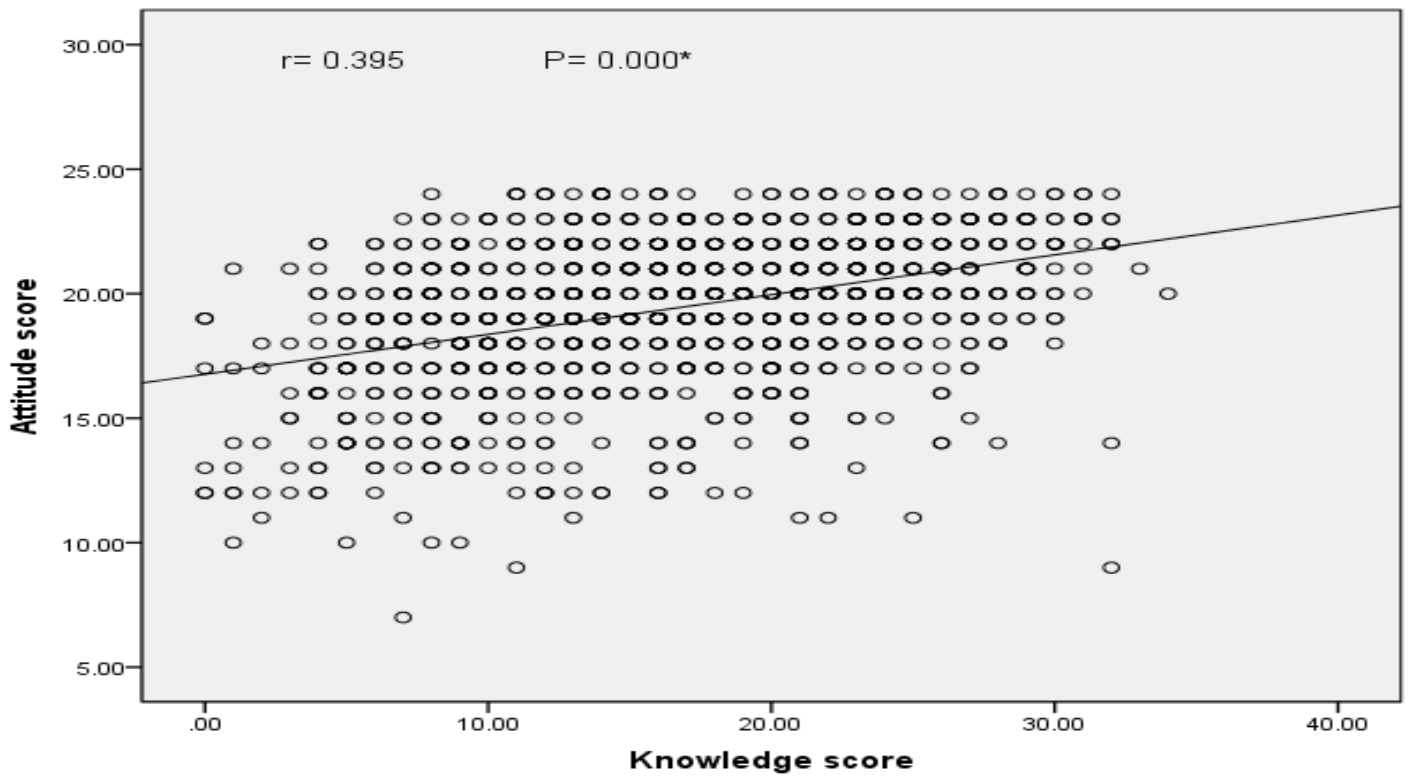

Fig. (3): Correlation between knowledge score and attitude score regarding global warming, Assiut University 2016, No. $(n=1300)$ 
Table (1): Shows that nearly two-thirds (64.0\%) of students' age 20 years and more. And more than half of them were males and form rural areas.

Also, more than one-quarter of the studied students were represented from $1^{\text {st }} \& 3^{\text {rd }}$ academic year $(27.4 \%$, 26.5\%) respectively. Regarding the socioeconomic level, it was observed that more than three-fifth $(63.4 \%)$ of students within middle level, $17.7 \%$ were low level and $18.9 \%$ were at high socioeconomic level.

Table (2): Regarding factors contributing to climate changes, the results displayed that $71.7 \%$ of the studied sample mentioned Human activities such as the exhaust fumes of cars, followed by $68.2 \%$ mentioned industrial pollution, $66.3 \%$ burning of waste materials and $65.2 \%$ of students mentioned the burning of agricultural wastes as factors contributing to climate changes.

Regarding to energy resources that cause environmental pollution leading to global warming, the results cleared that more than half $(59.2 \%)$ mentioned coal, and less than one third (31.0\%) mentioned oil.

Table (3): This table reveals students' knowledge regarding to the global warming effects on humans, it was noticed that $47.6 \%$ of the studied students stated respiratory problems, followed by increase the incidence of skin cancer and increase transmission of diseases (46.1\% and $38.0 \%$ respectively).

Table (4): Clears that; more than half $(51.7 \%)$ of the students mentioned that industrial security considered the main solution to reduce global warming, followed by $(48.8 \%)$ mentioned that use of bikes as the second way to reduce global warming, and $45.0 \%$ of them mentioned that traffic security and cars maintenance are the important ways to reduce this phenomenon. While, the majority of the studied students $(80.8 \%)$ mentioned that the sun energy is the main source of alternative energy, followed by $61.5 \%$ mentioned wind energy.

Table (5): Shows that more than one fifth (22.3\%) of Commerce students' have good level of knowledge, about two fifths $(39.6 \%)$ of Science students' have a satisfactory knowledge and more than three-fifth $(61.8 \%)$ of Law students' have poor knowledge.

On the other hand, the table reveals that more than half $(54.2 \%)$ of third-year students' have poor knowledge and about one quarter $(24.6 \%)$ of fourthyear students' have good knowledge. Also, the table indicates that a significant difference between institution and academic year $(\mathrm{P}=0.000, \mathrm{P}=0003$ respectively) in relation with students' score of knowledge concerning global warming.

Table (6): Presents that vast majority (95.8\%) of students at Faculty of Science have positive attitude with regard global warming. Also, It's important to notice that, there is a statistical significant difference between studied students' attitude and their institution and academic year $(\mathrm{P}=0.000)$.

Table (7): Clears that, the majority of the studied students agreed that global warming affect human health and it's an universal phenomenon $(89.5 \%$ and $88.6 \%$ respectively).

Fig. (1): Reveals that about half $(49.0 \%)$ of the studied students had poor score of knowledge, and about one third $(32.8 \%)$ of them had fair level of knowledge while only $18.2 \%$ of them had good score of knowledge about global warming.

Fig. (2): Shows that the majority $(92.9 \%)$ of studied students had a positive attitude regarding global warming.

Fig. (3): This figure indicates a positive correlation between knowledge \& attitude score regarding global warming among the studied students $\mathrm{r}=0.395$ with statistically significance difference $\mathrm{P}=0.000$.

\section{Discussion}

People, animals, birds, agriculture and habitat affected in many and different ways by global warming (Goel \& Bhatt 2012).

The current study findings shown that more than half of the studied students were males. It is may be as a result of the number of male students more than females especially in theoretical colleges. This finding in line with (Aydine, 2010) who studied the secondary school students' perceptions towards global warming: A phenomenographic analysis in Turkey.

The present study disagreed in sex with (Heged et al., 2012) who assessed the awareness of school teachers about global warming in coastal Karnataka in India they reported that the majority of his study' participants were females.

In addition, the study indicated that more than half of students were from rural areas. These outcomes in accordance with (El-Nagar et al., 2017) who reported that about two-third of their students were from rural areas. In contrast (Sah et al., 2015) who reported that near to three-quarter of the study participants were from urban areas.

As regards to students' knowledge regarding factors contributing to climate changes, the current study verified that more than two-thirds of studied student mentioned human activities, followed by industrial pollution. The same finding was found by

(Al Buloshi \& Ramadan 2015) who reported that the most participants mentioned human activities followed by industrial sector.

Based on the present study, it was found that near half of the students mentioned respiratory problems and only $14.9 \%$ mentioned malnutrition as essential properties of global warming effects on human 
health. Respiratory problems may occur as a result of fossil fuel burning in vehicles, create electricity and deforestation. Additionally, food and crops will expose to reduce when Earth temperature increase leading to malnutrition.

This finding was similar to (Sah \& Belled, 2015) who carried a study on south India, where the majority of the studied students considered cardiovascular and respiratory problems and only $4 \%$ considered malnutrition the major health effects of global warming.

The existing study exposed that, the majority of students stated sun energy and more than three-fifth of them mentioned wind energy as important sources of alternative energy. Sun and wind energy considered the main sources of clean energy, because it is environmental friendly energy sources and not producing greenhouse gases.

The current study result was consistence with (Nuryadin 2016), who conducted a study among Universitas Negeri Jakarta students, Indonesia. He reported that the vast majority of studied students said that global warming can be lessened by wind and sun energy.

In general, the present study confirmed that about half of the students had a poor score of knowledge. Also, about one third had fair, and near of one fifth had a good score of knowledge about global warming.

The current study results agree with (Rosidin \& Suyatna 2017) who conducted a study on teachers and students knowledge about global warming: a study in smoke disaster area of Indonesia and based on the results of data analysis, their study concluded that the knowledge of teachers and students about global warming is very low. This results in agreement with the current study. In addition, the present study finding supported by (Chakraborty et al., 2015) in India, who cleared that the initial knowledge was particularly low.

The results of the existing study also disagree with (Freije et al., 2016) who study global warming awareness among the University of Bahrain science students and found excess than half of studied students offered correct answers as regards global warming.

(Ochieng \& Koske 2013) who studied the level of climate change awareness and perception among primary school teachers in Kisumu municipality, Kenya, they reported that level of climate change awareness among primary school teachers is low (2.2\%), medium (70.8\%), high $(27.0 \%)$, and it concluded that the level of climate change awareness among primary school teachers in Kisumu municipality is good. These results disagree with the findings of current study.
The current study appeared that the vast majority of the studied students had positive attitude toward global warming. However, this results in contrary to (Adio-Moses \& Aladejana 2015), Nigeria who reported that only one-quarter of studied sample had positive attitude.

Faculty of Science students', their attitude is positive in relation to global warming in the current study; this is may be as a result of students study part about global warming in their curriculum. Also, the vast majority of fourth-year students have positive attitude and about one-quarter of fourth-year students have good knowledge this may be as a result of accumulated knowledge about global warming throughout academic years.

The current study concluded that; a significant difference between the academic year and students' knowledge \& attitude scores concerning global warming. This is may be as a result of students gaining knowledge throughout the academic learning. This result was similar to Sah, et al., (2015) India, and Freij et al., (2016).

A significant difference in the contemporary study appears between the type of institution (faculty) and students' knowledge and attitude concerning global warming which can be attributed to the involvement of environmental related topics in practical colleges' curriculum.

The current study results in accordance with (Sharmila \& Pillai 2012) India who reported a significant difference among art and science group students in respect to their knowledge regarding global warming. Also, (El-Nagar et al., 2017) Egypt, who found a significant difference between literary and scientific type of faculty in relation to items of perception and cues of action about global warming.

\section{Conclusion}

The majority of studied students had a positive attitude toward global warming although; about half of them had poor knowledge toward this phenomenon.

\section{Recommendations}

\section{The study recommended that}

- Integrating environmental concepts into the university curriculum for all students irrespective of their academic specialization in order to increase their environmental awareness

- Periodic health education programs regarding global warming are needed to create awareness among the school and university students.

- Further researches in the field of global warming phenomenon. 
- A guidline book should be disseminated to all university students to increase their awareness about global warming phenomenon.

\section{References}

1. Abd El-Rhman M., (2014): Knowledge and opinions of Assiut university Students toward organ donation and transplantation ,submitted for partial fulfillment of the requirement of the master degree in community health nursing, faculty of Nursing ,Assiut university pp 60-61.

2. Abd El-twab A., (2012): Socioeconomic scale, Faculty of Education, Assiut Unoversity.

3. Adio-Moses R., \& Aladejana J., (2015): Assessment of knowledge and awareness of global warming among inhabitants of industrial areas of an urban community in a developing country, The Business and Management Review, vol 7(1),pp. 423,424.

4. Afzal B., (2007): Global Warming: A Public Health Concern , OJIN: The Online Journal of Issues in Nursing, Vol. 12(2).

5. Al Buloshi A., \& Ramadan E., (2015): Climate change awareness and perception amongst the inhabitant of Muscat Governorate, Oman, American Journal of Climate Change, vol. 4, pp. 330-336.

6. Aydin F., (2010): Secondary school students' perceptions towards global warming: A phenomenographic analysis, Scientific Research and Essays Vol. 5(12), pp. 1568.

7. Chakraborty D., Mondal T., Mojumdar D., \& Naskar N., (2015): An intervention Study on Knowledge of Global Warming among School Students of Kolkata, West Bengal, India, Journal of Dental and Medical Sciences,vol 14 (12),pp.14.

8. DeMarco R., \& Harkness G., (2016): Community and Public Health Nursing evidence for practice, Environmental Health, $2^{\text {nd }}$ ed., Wolters Kluwer, P 397.

9. El-Nagar S., Abd Elsalam E., \& Ahmed N., (2017): Effect of Instruction with Visual Materials Based on Health Belief Model on Global Warming Perception Among University Students, American Journal of Nursing Science, vol.6(3),p 209-217.

10. Fouad S., (2014): Environmental Reform in Egypt: The Past Mistakes, Present, Cairo University: Journal of Environment and Earth Science, vol 4,pp2224-3216 (Paper) ISSN 22250948 (Online).

11. Frances M., \& Glaudia S., (2013): Community/public health nursing practice health for families and populations, Environmental health risks: at home at work and in the community, $5^{\text {th }}$ ed., Elsevier Saunders, library of congress in publication data, pp237.

12. Freije A., Hussain T., \& Salman E., (2016): Global warming awareness among the University of Bahrain science students. Journal of the Association of Arab Universities for Basic and Applied Sciences, vol. 22, pp.1-16.

13. Goel A., \& Bhatt R., (2012): Causes And Consequences Of Global Warming, international journal of life science biotechnology and pharma research, Vol. 1(1), Pp. 29, 30.

14. Hegazy A., (2009): State Of Environment: Egypt, Geo South-Eastern Europe and Eastern Mediterranean Symposium On Earth Observation Services for Monitoring the Environment and Protecting the General Public.

15. Hegde S., Murthy N., Shalini C., \& Sandeep K., (2012): Awareness of global warming among school teachers in costal Karnataka, India J Prev Soc Med. Vol.43 (4), p 368.

16. Hunt, G., (2007): Global Warming and the Future of Healthcare and Nursing, Royal College of Nurses Annual Congress.

17. Ibrahim H., Ahmed A., Gadallah M., \& Hussien A., (2009): Nutritional and exercise habits for prevention of osteoporosis among female adolescents in Assiut City secondary school, the new Egyptian journal of medicine vol:41;No:4,Pp346-356.

18. Khalaf F., (2012): Knowledge and Attitude of Assiut University Dorms Students about consanguinity marriage, thesis submitted for partial fulfillment of the requirement of the master degree in community health nursing, faculty of Nursing, Assiut university, pp 158-159).

19. Liarakou G., Athanasiadis I., \& Gavrilakis G., (2011): What Greek secondary school students believe about climate change? Int. J. Environ. Sci. Educ., 6 (1) (2011), pp. 79-98

20. Netravathia G., \& Chauhan N., (2014): A Scale to Measure Attitude of Research Scholars towards Climate Change Studying in Agricultural Universities, Indian Res. J. Ext. Edu, vol. 14 (1), pp. 83-86.

21. Nuryadin S., (2016): The perceptions of environmental knowledge, global warming and attitude towards energy and water universitas Negeri Jakarta students, International Journal of Research in Applied,Natural and Social Sciences , vol. 4(11), pp. 113-122.

22. Ochieng M., \& Koske J., (2013): The Level of Climate Change Awareness and Perception among Primary School Teachers in Kisumu Municipality, Kenya, International Journal of Humanities and Social Science, Vol.3(21), pp. 174-179. 
23. Patz J., Frumkin H., Holloway T., Vimont D., Haines A., \& Jama (2014): Climate Change Challenges and Opportunities for Global Health,vol 312 (15),pp 1567.

24. Raina S., (2013): Assessment of Knowledge, Attitude, and Practice in Health Care Delivery, Nourth American Journal of Medical sicences, 5(3): 249-250.

25. Rosidin U., \& Suyatna A., (2017): Teachers and Students Knowledge about Global Warming: A Study in Smoke Disaster Area of Indonesia, International Journal Of Environmental \& Science Education, Vol. 12 (4), p. 777.

26. Rosidin U., \& Suyatna A., (2017): Teachers and Students Knowledge about Global Warming: a Study in Smoke Disaster Area of Indonesia, International Journal Of Environmental \& Science Education, vol. 12 (4), Pp 785.

27. Saber M., (2009): Environment in Jeopardy: Consequences of climate change in Egypt, Journal of Ecology and the Natural Environment, vol. 1 (5), pp. 191-195.

28. Sah J., \& Belled A., (2015): Awareness and knowledge about global warming among school students of south India, US National Library of Medicine enlisted journal, vol. 8(3), p230-234.

29. Sah J., Bellad A., \& Angolkar M., (2015): Assessement of the knowledge and attitude regarding global warming among high school students of Ramnagar, Belagavi city: A crosssectional study, Journal of dental and medical sciences, Vol.14 (4), pp. 374-320.

30. Sharmila V., \& Pillai K., (2012): College student's knowledge about global warming, International journal of current research, vol. 4(1) pp. 157-159. Available online at http://www.journalcra.com.

31. World Health Organization (WHO 2015): Climate and health countryprofile,Egypt,http://www.who.int/globalch ange/resources/country-profiles/PHE-countryprofile-Egypt.pdf?ua $=1$

32. Zameel A., Chethan K., \& Udaya N., (2013): Global Warming: its Implications Among The college Students of Manglore city, India, Journal of Evolution of Medical and Dental Sciences, vol. 2(28),pp. 5081-5087 . 